\title{
A MORTE MORAL E A ECONOMIA DOS DESEJOS NO EMÍLIO DE ROUSSEAU ${ }^{1}$
}

\author{
Natalia Maruyama \\ PUC-Campinas
}

\begin{abstract}
The anthropology developed by Rousseau in Émile is part of a project to a moral restoration. When he returns to the analysis of the passions, the ideas of freedom, strength and virtue and the foundations of moral feelings, the author outlines the economy of desires. We must draw attention to the political aspects involved in these conceptions, which allows us to treat them in all their materiality, and not only as parts of a system of abstract thought. Thus, both the moral feelings, as the passions and desires, and the conception of will, are examined, not only in its strictly moral sense. Taken to the extremes of morality, they show us the link between the physical and the spiritual, but also indicate a point of rupture in the manifestations of the voice of conscience, regression that characterizes what we call moral death.
\end{abstract}

Key Words: Enlightenment, moral, freedom, passion, Rousseau.

Resumo: A antropologia elaborada por Rousseau no Emílio faz parte de um projeto de restauração moral. Quando se volta à análise das paixões, às concepções de liberdade, força e virtude e à fundamentação dos sentimentos morais, o autor esboça a economia dos desejos. Cabe-nos chamar atenção para os aspectos políticos implicados nessas concepções, o que nos permite tratá-las em toda a sua materialidade, e não apenas como peças de um sistema de pensamento abstrato. Assim, tanto os sentimentos morais, como as paixões e os desejos, e a própria concepção de vontade, são examinados, mas não apenas em seu sentido estritamente moral. Levados aos extremos da moralidade, mostram-nos o vínculo entre o físico e o espiritual, mas indicam também um ponto de ruptura nas manifestações da voz da consciência, regressão que caracteriza o que chamamos de morte moral.

Palavras-Chave: Iluminismo, moral, liberdade, paixões, Rousseau.

\footnotetext{
1 Neste texto retomo parte de um estudo anterior sobre a obra Emílio ou Da Educação, mais particularmente acerca da educação negativa, realizado no período em que estive na Universidade Federal do Paraná, entre março de 2003 e fevereiro de 2007, pelo Programa Prodoc da Capes.
}

(C) Dissertatio [29], $183-200$ inverno de 2009 
$\mathrm{O}$ pessimismo de Rousseau vincula-se à sentença histórica de que a sociedade corrompe porquanto o homem é originalmente bom. Sua segunda grande obra, o Discurso sobre a origem da desigualdade entre os homens, a partir da idéia de uma história hipotética da humanidade, permeada de conceitos filosóficos, mostra-nos a decadência do homem em seu percurso em direção de formas de organização mais sofisticadas de sociedade. À medida que se desenvolvem processo produtivo, idéias morais, propostas de organização política e laços afetivos entre os homens, eles conhecem miséria, opressão e, de seres uniformes que eram no suposto estado de natureza, passam a viver uma contradição interior. No decorrer de tal processo consuma-se uma ruptura nas relações do homem consigo mesmo. Quanto mais ele se associa aos outros, mais parece distanciar-se de si mesmo. Ocorre uma espécie de alienação provocada pelas associações com os outros, e a decadência moral que as acompanha é expressão fulgente dessa perdição.

A questão aqui consiste em saber como explicar do ponto de vista antropológico os males provenientes das condições sociais. Essa análise envolve, ao mesmo tempo, considerações de ordem moral e política e reflexões sobre o desenvolvimento das paixões humanas. Como não é possível separar as condições materiais exteriores das qualidades internas do sujeito das paixões, podemos notar que, a cada elemento exterior da história da humanidade - surgimento da propriedade privada, divisão do trabalho, invenção da metalurgia - corresponde um acréscimo na interioridade. Todavia, cabe notar, esses acréscimos, que caracterizam mais propriamente o desenvolvimento e o dinamismo da natureza humana, do ponto de vista de nosso autor podem ser pensados concomitantemente a uma regressão ou perversão no sentido moral. $\mathrm{O}$ sujeito das paixões, eu humano ou natureza humana, articula-se como combinações de fenômenos do espírito e efeitos provenientes do corpo, ambos imanentes à história, não havendo separação radical entre o dentro e o fora. Podemos dizer que os males decorrentes do processo de civilização são duplos, simultaneamente físicos e mentais, materiais e simbólicos; em nenhum desses casos, esses males humanos deixam de ser de cunho moral.

Retomamos o problema da morte moral, esboçado na obra Emílio ou Da Educação, problema ligado àquele que é considerado o núcleo mesmo do pensamento do autor: o vínculo entre o mal humano, a racionalidade e o desenvolvimento das paixões. É claro que, para isso, outras questões deverão ser abordadas, como aquela que diz respeito à relação entre força e 
necessidade, e às concepções de liberdade e desigualdade. Cabe ressaltar que este estudo exige uma análise prévia do problema do primado da sensibilidade sobre a razão, que serve aqui apenas de pressuposto, já que fora tratado anteriormente. Nosso objetivo é mostrar, a partir do exame dessa obra de Rousseau, como a análise das paixões e dos desejos contribui para suas reflexões acerca da natureza humana no momento em que se tratava de elaborar um discurso persuasivo no âmbito da moral e da religião. Não buscamos propriamente uma solução prática para o problema da morte moral, tal como diagnosticada por Rousseau. Apontamos, todavia, no final deste texto, para a possibilidade de uma restauração moral, paralela àquela formulada no Contrato social, que passa também pela questão política. Do ponto de vista do desenvolvimento das paixões e da sensibilidade humana, essa restauração moral supõe uma educação segundo os princípios negativos da educação da natureza, proposta na obra Emílio².

A decadência moral da humaniodade é tratada ao longo de toda a trajetória intelectual de Rousseau. Não bastava para ele a crítica ao desenvolvimento das artes e das ciências, mas era preciso mostrar que a perversão moral é ocasionada pela ausência de princípios ou critérios de ação num contexto em que, não apenas as opções éticas estão em jogo, mas, também estão às determinações materiais, as condições e os modos de vida, a organização social, econômica e política. Como explicar, nesse sentido, o dever para aquele que não tem o que comer? Como pensar os princípios da educação num ambiente de corrupção generalizada? Que tipo de proposta se pode formular no âmbito político diante de um governo autoritário e de um conjunto de indivíduos passivos e desinteressados?

No que concerne à perspectiva antropológica, que nos interessa aqui mais particularmente, nosso autor apresenta os sentimentos morais como sendo inatos, apesar de não termos idéias inatas acerca da justiça, do bem e do mal, do vício e da virtude. Segundo Rousseau, assim que formulamos tais idéias na mente, estamos prontos a amar aquilo que elas representam; esse amor é inato. A pré-história dos sentimentos morais é mostrada no tratamento do tema da piedade natural, princípio biológico, tal como vemos na Primeira Parte do Discurso sobre a desigualdade, mas que se desdobra nos sentimentos de humanidade, comiseração e justiça, enfim, princípio que

${ }^{2} \mathrm{~A}$ edição de referência para os textos de Rousseau é 0 da Bibliothèque de la Pléiade: Oeuvres complètes de Jean-Jacques Rousseau. Paris: Gallimard, 1964-1995. 5 v. 
explica a possibilidade de existência dos sentimentos morais. Conhecemos as considerações de Rousseau acerca da corrupção do princípio da piedade. Assim como os sentimentos morais em geral, a piedade natural não desaparece, jamais é inteiramente aniquilada, mas pode emudecer diante de condições que lhe sejam desfavoráveis. Portanto, apesar de possuirmos sentimentos nobres referentes à moralidade, apesar de sermos orientados por esse princípio anterior à razão, que é a piedade natural, vivemos frequentemente sob condições que nos levam à negação da justiça, da virtude e da bondade.

Tal era, pois, a questão apresentada em uma nota escrita pelo próprio autor no Discurso sobre a desigualdade:

Os homens são maus, uma triste e contínua experiência dispensa a prova; entretanto, o homem é naturalmente bom, creio havê-lo demonstrado. Que será, pois, que o pode ter depravado a esse ponto, senão as mudanças sobrevindas na sua constituição, os progressos que fez e os conhecimentos que adquiriu? ${ }^{3}$

Se nessa obra de 1755 o autor fala, pois, em depravação, ou em deformação da natureza humana, como vemos no Prefácio, na obra Emílio, de 1762, temos referências à degeneração e à morte moral. O que seria morrer do ponto de vista moral, segundo Rousseau? A pretensão de se falar na morte moral exige, antes, que se contextualize o uso da expressão moral em seus textos, já que esta expressão nos aponta ao mesmo tempo para o plano espiritual e para o plano físico. Além disso, no Discurso sobre a desigualdade é clara a afirmação de que é compatível a degeneração moral com o desenvolvimento das faculdades mentais e dos órgãos corporais.

Os sentidos do termo moral no século XVIII abarcam o domínio das idéias de bem e mal, de vício e de virtude, correspondendo, mais particularmente, ao domínio da moral como disciplina ou ciência dos costumes, mas concernem também às categorias distintas daquelas do mundo "físico". Nesse último sentido, o termo "moral" era empregado pelos filósofos para se referirem a um outro mundo, distinto daquele dos corpos e da matéria. No artigo "Homem", da Enciclopédia ou Dicionário Raciocinado das Ciências, das Artes e dos Oficios",

\footnotetext{
${ }^{3}$ Oeuvres complètes de Jean-Jacques Rousseau. Paris: Gallimard, 1964, v. 3, p. 202, nota IX.

${ }^{4}$ Cf. Encyclopédie ou Dictionnaire Raisonné des Sciences des Arts et des Métiers, de Diderot e d'Alembert, nova impressão em fac-símile da primeira edição (1751-1780). Stuttgart: Bad Cannstatt, 1988. Há traduções em português de alguns verbetes da Enciclopédia (VERBETES políticos da Enciclopédia de Direrot e d’Alembert. São Paulo; Marília: Discurso; Unesp, 2006), assim como de seu
} 
de Diderot e d'Alembert, há uma busca pelos motivos naturais que determinam as ações humanas. Para se compreender o homem do ponto de vista moral, o autor, Le Roy, se refere à sensibilidade fisica (faculdade de sentir) como princípio de nossas idéias e de nossos conhecimentos, e também como desejo, isto é, princípio de nossos movimentos e de nossas inclinações. Nessas passagens de texto, em que se trata de compreender o moral no homem, é sempre ao processo psicológico que o autor se refere.

O "moral”, em contraposição ao "físico", aparece em vários outros artigos da Enciclopédia. Por exemplo, no artigo "Observações Celestes", quando se diz "Podemos considerar o homem sob dois pontos de vista principalmente: o Moral ou o Físico" ou, ainda, como no artigo "Loucura", onde encontramos referências a uma "loucura física" e a um outro tipo de loucura, a "loucura moral". Com efeito, há uma distinção entre o "físico" e o "moral”, mas que não implica, notemo-lo, que o físico e o moral não mantenham relação de interdependência. Assim, encontramos a seguinte observação de Jaucourt, no artigo "Humor", quando se refere ao bom humor, no sentido moral: "O bom humor, nota o autor, é uma espécie de desabrochar da alma contente produzido pelo bom estado do corpo e do espírito". Também no artigo "Sensibilidade, Sentimento", da Enciclopédia, o médico Fouquet, ao se referir à influência do clima, dos astros e da alimentação na alma sensível, isto é, ao se referir aos efeitos da sensibilidade, afirma a dependência recíproca entre as "idéias físicas" e as "idéias morais".

"Moral", nesse sentido, designava no século XVIII francês, o que faz parte do espírito ou da alma e se confundia por vezes, assim, com o que é de ordem espiritual ou psicológica. Rousseau, em diversas passagens de seus textos, emprega o termo nesse sentido mais geral. No Discurso sobre a desigualdade, por exemplo, na exposição de seu quadro (o tableau) do homem natural, ele separa o aspecto que chama moral ou metafisico ${ }^{5}$, daqueles que caracterizam o homem físico, temas sobre a saúde e a doença, o corpo e sua evolução na história da espécie humana. Assim, após tratar da conformação física do homem, de seu corpo e do desenvolvimento dos órgãos corporais, ele passa à descrição de outras qualidades, incorporando as paixões, as associações de idéias e outros elementos que, segundo ele, fazem do homem um ser privilegiado da natureza.

Discurso Preliminar (ENCICLOPÉDIA ou Dicionário Raciocinado das Ciências, das Artes e dos Ofícios. Discurso Preliminar e outros textos, ed. bilíngüe, trad. F. M. L. Moretto. Marília: Unesp, 1989).

${ }^{5}$ Oeuvres complètes de Jean-Jacques Rousseau, op. cit., v. 3, p. 141. 
Entretanto, há aqui um elemento complicador. Podemos notar que mesmo aqueles que não concordam que o homem tenha uma posição privilegiada na cadeia dos seres naturais - como era o caso dos filósofos franceses materialistas do século XVIII - partem da idéia de que há alguma conexão, ou até mesmo uma identificação, entre mundo físico e mundo moral. Segundo La Mettrie, que sustenta sua filosofia em suas pesquisas sobre o corpo humano, o homem é um ser uno, ele é ao mesmo tempo corpo e alma. As paixões e as faculdades intelectuais não podem ser consideradas independentes do corpo. Helvétius, por sua vez, afirma em várias passagens de sua obra a existência de leis comuns à física e à moral. No capítulo 1 do Discurso III de sua obra Do Espírito ${ }^{6}$, por exemplo, referindo-se às diferenças de talento, de espírito e de gênio entre os homens, Helvétius observa que, na Física como na Moral, os maiores acontecimentos são freqüentemente efeitos de causas quase imperceptíveis. Não há aqui reconhecimento de uma esfera autônoma do mundo físico. Sabemos que esse autor é um dos principais interlocutores de Rousseau, tendo sido, segundo alguns intérpretes, para refutar sua tese da sensibilidade física que nosso filósofo teria redigido a passagem do Livro IV do Emílio intitulada Profissão de fé do vigário saboiano.

Sabemos que Rousseau, embora parta das teses sensualistas, segundo as quais tudo o que temos no espírito passa pelas sensações, não absorve suas conseqüências éticas. A fecundidade do princípio da sensibilidade física apontada pelos filósofos materialistas, como radicalização do sensualismo projetado por Locke e Condillac, só pode ser compreendida, do ponto de vista de Rousseau, como elemento pré-moral. Tal como examinado anteriormente, em outro estudo, se esse princípio pode nos levar tanto ao bem quanto ao mal, tanto ao vício quanto à virtude, é porque caracteriza mais a formação ou funcionamento das idéias e das faculdades mentais, consideradas de modo geral, do que a formação dos juízos morais. Esse princípio não é, portanto, constitutivo da moralidade enquantal tal, em nada nos ajuda a explicar, por exemplo, o princípio do dever. A sensibilidade física é o motivo que faz os homens agirem, independentemente do que podemos fixar como sendo bom, virtuoso ou verdadeiramente desejável e interessante. A sensibilidade física dos materialistas é, portanto, pré-moral. Além de sua indeterminação moral, pretende-se que ela seja anterior à ação praticada em

${ }^{6}$ HELVÉTIUS, Claude-Adrien. De l'Esprit, segundo a ed. de 1758, texto revisado por J. Moutaux. Paris: Fayard, 1988 (Coleção Corpus des Oeuvres de Philosophie en Langue Française). 
benefício de uma coletividade ou em função das regras dessa coletividade. Vale notar, então, que no XVIII francês o termo moral designa também aquilo que pertence à vida social e caracteriza a disciplina do conhecimento que se encarrega das regras do bom convívio ${ }^{7}$.

O que nos importa ressaltar é o vínculo estreito entre o físico, o natural, o moral e o social. Notamos que não há incompatibilidade do social ou artificial, plano das coisas construídas pelas mãos ou pelo espírito humano, com o natural. Em diversos artigos de Jaucourt, publicados na Enciclopédia ${ }^{8}$, encontramos, ainda, uma referência à moral como conhecimento dos valores e das normas de conduta, cuja necessidade se impõe aos homens independentemente de suas diferenças subjetivas ou individuais. Entretanto, o termo é também empregado para ressaltar a preeminência das regras naturais, tais como as que provêm diretamente dos prazeres e das paixões de cada um. Todas essas nuanças implicadas nos vários sentidos do termo moral marcam a variedade das doutrinas morais no XVIII francês, sem, contudo, esgotá-las. Esses sentidos do termo moral dão conta, todavia, da quase totalidade das discussões sobre o objeto e a finalidade específica da moral no sentido estrito desse termo, isto é, em sua relação com os temas da virtude, da liberdade e da vontade, do bem e da felicidade. Há aqui dois aspectos relacionais: de um lado, o moral que se correlaciona com o que é físico e, de outro, as faculdades e disposições humanas em sua integração com as situações, circunstâncias e influências exteriores. Não por acaso, o elemento de ligação em ambos os casos pertence ao corpóreo. Entre o físico e o moral, temos as sensações, o prazer; a sensibilidade física de Helvétius, por exemplo, faz o elo entre mundo físico e mundo moral. No outro conjunto de pares que se interligam, temos, entre o sujeito e as condições exteriores, a liberdade. Esse é o caso de Rousseau. Voltemos, então, a sua obra.

O homem realmente livre é, como nota no Livro II do Emílio, aquele que «só quer o que pode e faz o que lhe apraz», é aquele que faz o que quer sem a necessidade dos outros, isto é, nas palavras do autor, é aquele que «não

\footnotetext{
${ }^{7}$ Esse é o sentido empregado pelo moralista Claude Buffier quando define a moral como ciência de viver com os outros homens na sociedade civil. Cf. seu Traité de la Société Civile et du Moyen de se Rendre Heureux, en contribuant au Bonheur des Personnes avec qui l'on vit. Avec d'Observations sur divers Ouvrages Renomez de Morale. Paris: Pierre-François Giffart, 1726, Livro I, Capítulo 1.

${ }^{8}$ Cf. os artigos de Jaucourt "Être (moral) », "Vie (morale) », " Moralité » e " Morale (Science des mœurs) », Encyclopédie ou Dictionnaire Raisonné des Sciences des Arts et des Métiers, de Diderot e d'Alembert (op. cit.). Para as referências gerais concernentes aos artigos da Encyclopédie, remetemovos ao livro de J. Lough, The Encyclopédie (1971, fac-sím. Genève, Slaktine, 1989).
} 
tem necessidade, para fazê-lo, de pôr os braços de outro na ponta dos seus»' É enquanto categoria da mente que experimentamos a perda da liberdade. Entretanto, como nos sugere essa passagem, isso não implica que haja, necessariamente, uma pressuposição acerca da transcendência da ordem moral ou metafísica. Podemos nos referir à liberdade humana compreendida, antes de tudo, como uma dádiva da natureza:

Ó homem! encerra tua existência dentro de ti e não serás mais miserável. Fica no lugar que a natureza te designa na cadeia dos seres, nada poderá arrancar-te dele; não te revoltes contra a dura lei da necessidade e não esgotes, querendo resistir-lhe, forças que o céu não te deu para prolongar tua existência e sim, tão somente, para conservá-la como lhe agrada e enquanto lhe agrada. Tua liberdade, teu poder só vão tão longe quanto tuas forças naturais, e não além; tudo mais não passa de escravidão, ilusão, prestígio ${ }^{10}$.

Enquanto dom da natureza, a liberdade é, portanto, princípio imanente e não transcendente ${ }^{11}$. Claro, para Rousseau, do ponto de vista material, trata-se de uma alienação da força de trabalho - o homem deixa de ser livre quando precisa colocar os braços de outros na ponta dos seus ${ }^{12}$. Essa perda de liberdade ou da dignidade, que rebaixa o homem ao nível dos outros animais, levando ao abandono de traços essenciais de sua natureza,

\footnotetext{
${ }^{9}$ Emílio, Livro II. In: Oeuvres complètes, op. cit., v. 4, p. 309.

${ }_{10} \mathrm{Ibid}$., Livro II, p.308.

${ }^{11}$ Remetemo-vos ao artigo de M. Rang, Le dualisme anthropologique dans l'Émile. In: Jean-Jacques Rousseau et son Oeuvre. Problèmes et Recherches. Paris: Klincksieck, 1964, pp. 195-203. Vale ressaltar que, para Rang, não precisamos supor uma relação de superação entre as várias fases por que passa Emílio até chegar à idade adulta, idade da razão.

12 Cf. ibid., Livro II, p.309-310: "A sociedade fez o homem mais fraco, não somente lhe tirando o direito sobre suas próprias forças, como também as tornando insuficientes. Eis porque seus desejos se multiplicam com sua fraqueza e eis o que faz a fraqueza da infância, comparada com a idade do homem. Se o homem é um ser forte e a criança um ser fraco, não é porque o primeiro tenha mais força absoluta que 0 segundo, mas é porque o primeiro pode naturalmente bastar-se a si mesmo e o outro não. $O$ homem deve portanto ter mais vontades e a criança mais fantasias, palavra com que quero dizer todos os desejos que não são necessidades reais, que só podemos contentar com o auxílio de outrem".

Com os homens em sociedade acontece o mesmo. Tal qual crianças, eles dependem em tudo uns dos outros: "não podendo prescindir dos outros, todos nós nos tornamos, desse ponto de vista, fracos e miseráveis. Éramos feitos para sermos homens; as leis e a sociedade nos mergulharam novamente na infância" (ibid., p. 310). Além dos laços de dependência material, no Emílio encontramos também o princípio da perfectibilidade humana, tão explorado no Discurso sobre a desigualdade, enquanto elemento que distingue o homem de outros seres da natureza. Os laços de servidão aparecem também no Emílio associados ao trabalho: "Todos os animais têm exatamente as qualidades necessárias para se conservarem. Só o homem as têm supérfluas. Não é estranho que esse supérfluo seja 0 instrumento de sua desgraça? (...) É à força de trabalhar para aumentar nossa felicidade que a transformamos em miséria. Todo homem que só quisesse viver, viveria feliz; consequentemente seria bom, pois que vantagem teria em ser mau?" (ibid., p. 305-306).
} 
são decorrências da civilização, mas são também experiências que só se tornaram possíveis através desse duplo civilização e natureza. A natureza é, nesse sentido, categoria ou invenção humana e social, porque o sujeito que a pensa também o é. Toda a caracterização das disposições primitivas que encontramos no Livro I do Emílio mostra-nos a peculiaridade da noção de natureza na obra de Rousseau: as disposições primitivas, embora ditas naturais, supõem em grande parte uma sofisticação nas capacidades morais e intelectuais. Do contrário, como poderíamos agir de acordo com as idéias que formamos de felicidade e de perfeição? ${ }^{13}$

No Discurso sobre a desigualdade, onde está em questão a dominação implicada nos três graus da desigualdade, Rousseau recorre à noção da independência natural ou à concepção metafísica da liberdade. Trata-se aqui, porém, de um princípio negativo. Em ambos os casos, isto é, seja considerando o isolamento dos homens no seio da pura natureza, seja atentando para uma liberdade essencial que lhes dá dignidade e caracteriza seus atos de vontade, o recurso à idéia da natureza se faz presente. Todavia, a natureza aqui assume a função de um princípio negativo, no sentido de que ela não está propriamente em lugar algum, dela não podemos excluir totalmente as conquistas do homem em sua vida social, moral, econômica e política. A solução para a dominação que se cria entre os homens ao longo de sua história vincula-se de algum modo à idéia mesma de natureza, mas, paradoxalmente, por outro lado, a independência ou liberdade, ao mesmo tempo natural e metafísica, só é efetivamente experimentada fora do puro estado de natureza. Curiosamente, essas considerações só podem ser feitas à luz da obra Emílio.

Nesse sentido, quando nos referimos à morte moral do homem, tal como encontramos no Livro IV dessa obra, não supomos meramente o abandono dos ideais da natureza ou alguma perda das referências clássicas quanto ao bem e ao mal, aos vícios e às virtudes. A morte moral é resultado final de uma regressão, regressão no sentido da impossibilidade em que se encontram os homens quanto à realização de suas capacidades. Embrutecimento e decadência propiciados pelas condições materiais que os impedem

\footnotetext{
13 Nascemos sensíveis, e quando tomamos consciência de nossas sensações nos dispomos naturalmente a procurar ou a fugir dos objetos que as produzem segundo estes três princípios: 1. Segundo sejam as sensações agradáveis ou desagradáveis; 2. Segundo a conveniência ou inconveniência que encontramos entre esses objetos e nós; 3 . Segundo os juízos que fazemos deles em relação à idéia de felicidade ou de perfeição que a razão nos fornece. Essas são, para Rousseau, as disposições ou inclinações naturais. Cf. ibid., Livro I, p. 248.
} 
de exercer suas disposições primitivas. A referência aqui não é, portanto, da ordem dos instintos que aproximam o homem dos outros animais, nem tampouco alguma faculdade nobre inerentemente espiritual. É bem para esse vínculo entre o espiritual e o instintivo, entre o humano e o puramente animal, entre a alma e o corpóreo, que nos chama atenção o autor.

Considerando a problemática do mal moral nessa perspectiva, pergunta-se Rousseau no Emílio, momentos antes de introduzir a Profissão de fé do vigário saboiano, o que seriam as leis da natureza, os gritos da consciência, naqueles que não têm o que comer, senão voz pungente, sonhos visionários ou surda incredulidade? Tal é a situação do interlocutor do vigário saboiano ${ }^{14}$, um fugitivo incrédulo, libertino, que se encontrava nos últimos graus da imoralidade, numa espécie de entorpecimento da alma manifesta numa orgulhosa misantropia.

Com efeito, nosso filósofo se reconhece na personagem, apresentandose na obra como o libertino solitário. Sua misantropia não se dirige contra a humanidade em geral, mas contra os ricos e venturosos:

O que havia em mim de mais difícil de destruir era uma orgulhosa misantropia, um certo amargor contra os ricos e venturosos do mundo, como se eles o fossem às minhas expensas e que sua pretensa felicidade houvesse sido usurpada da minhat ${ }^{15}$.

No contexto em que todos os males morais caracterizam-se como obra humana, criação da imaginação, atribuição subjetiva de intenções, crime à espera de castigo, reação às injustiças alheias ou efeito da dominação, a incredulidade é sinal de fraqueza. Não é um acaso que, tendo passado uma vida de miséria, tormentos e decepções, nosso fugitivo se encontre desacreditado do bem, da humanidade e da virtude. A religião para ele é embuste, coisa interesseira, e o caminho da felicidade, um logradouro de sentimentos azedos, estratagemas hipócritas e contradições. Não é propriamente a maldade que se instala na raiz de sua incredulidade, ela não está na origem da má consciência. O libertino não é mau per se, ele é imoral, não porque tenha alguma perversidade inata ou consentida, mas porque perdeu os parâmetros da moralidade; ele é caracterizado como aquele que esqueceu tudo o que importava saber, em quem a voz interior emudeceu, sufocam os sentimentos do bem e do mal e, sobretudo, desespera a felicidade.

\footnotetext{
${ }^{14}$ Tanto o libertino, como o vigário, são personagens lançados apenas no Livro IV do Emílio.

15 Ibid., Livro IV, p. 564.
} 
A miséria do homem decorre de que, pela educação recebida nesses períodos de acelerado aperfeiçoamento, os homens não conseguem medir o poder de suas faculdades, seus limites. Desse ponto de vista, a conseqüência mais nefasta do chamado progresso é a extensão de seus desejos e de suas falsas necessidades para além de suas capacidades ${ }^{16}$. Que não nos enganemos, nossa felicidade é um estado negativo, apenas uma questão de proporção entre dor e prazer, ela só se determina pela quantidade de desejo, portanto, pela diminuição da distância entre nossas aspirações e aquilo que as resolve.

Todo sentimento de dor é inseparável do desejo de dele livrar-se; toda idéia de prazer é inseparável do desejo de gozá-lo; todo desejo supõe privação, e todas as privações que sentimos são dolorosas; é então na desproporção de nossos desejos e de nossas faculdades que consiste nossa miséria. Um ser sensível cujas faculdades igualassem os desejos seria um ser absolutamente feliz ${ }^{17}$.

Transformando uma privação em aquisição, temos o gozo do prazer ou a extinção da dor, cujos extremos seriam um desejo consumado. Entretanto, a rota da felicidade nos leva bem longe, e essa é uma das lamentações de Rousseau contra o movimento geral de seu século, quando se vive, com os ideais do esclarecimento e a fabricação de novos modelos e utensílios, uma perpetuação do desejo. Trata-se de uma sátira amarga de meu século, pensava o autor.

A idéia de ordenação aparece como uma via para a verdadeira felicidade. Equilibrar o poder e a vontade, fazendo com que os desejos não transcendam as faculdades, é uma maneira que o homem encontra para viver mais feliz e serenamente. Não se trata de diminuir os desejos, pois isso poderia acarretar o ócio no exercício das faculdades, nem tampouco de ampliar essas últimas. Pretender superar o problema através dessa ampliação é pura ilusão.

Não ides imaginar porém que, ampliando vossas faculdades ampliais vossas forças; vós as diminuis, ao contrário, se vosso orgulho aumenta mais do que elas. Meçamos portanto o raio de nossa esfera e fiquemos no centro como o inseto no meio de sua teia; sempre nos bastaremos a nós mesmos e

\footnotetext{
${ }^{16}$ Vê-se no Discurso sobre a Desigualdade que, vivendo em sociedade e sendo nela educado, o homem ganha novas necessidades que lhe são estranhas e com elas novas ilusões. Esse tema é recorrente na literatura do século XVIII francês, e aparece também nos cursos de Condillac, sendo determinante na época para se discutir a economia política. Cf. Le Commerce et le Gouvernement. Genebra: Slatkine, 1980.

${ }^{17}$ Emílio, Livro II, op. cit., p. 303.
} 
não teremos que nos queixar de nossa fraqueza, porquanto não a sentiremos nunca ${ }^{18}$.

Se o homem natural está mais próximo da felicidade, é porque suas condições favorecem o equilíbrio entre poder e desejo, entre força e vontade. Ser forte e ser fraco, noções chaves para entendermos o diagnóstico dado por Rousseau aos males de seu século, são estados da natureza humana que não podem ser caracterizados separadamente, mas dependem da proporção entre forças naturais e necessidades. Aquele cujas forças ultrapassam a necessidade é um ser forte e aquele em quem, ao contrário, as necessidades ultrapassam a força é um ser fraco. Partindo dessa caracterização, conclui-se que o homem nas sociedades modernas é enfraquecido pela educação, pois aprende a projetar seus desejos e a inventar novas necessidades para além de suas forças naturais.

Força e fraqueza integram as concepções de bem e mal, de vício e virtude, e Rousseau as distingue conforme sejam consideradas em relação a um momento particular da vida ou como resultado de um combate. Por exemplo, na puberdade, a criança atinge o máximo de força para o mínimo de necessidades. Entretanto, sendo considerada isoladamente, essa força não tem ônus moral, é uma força relativa, ao passo que, posteriormente, cabe falarmos numa força absoluta, aquela que se impõe apesar dos obstáculos e das adversidades. O período que vai do nascimento à adolescência seria em si mesmo um tempo de fraqueza: qualquer força aqui pressuposta deve ser caracterizada como força relativa. Se Rousseau pode considerar Emílio como um ser forte mesmo durante esse período, é porque, em função da aplicação dos princípios da educação negativa, ele desenvolveu poucas necessidades, e a insistência em sua educação corporal o fez desenvolver as forças físicas, assim como as forças do espírito que as dirigem. Com efeito, no entender de Rousseau, a boa educação corporal importa, não somente para o desenvolvimento físico, a formação do corpo sadio e vigoroso, mas também para o desenvolvimento do espírito.

Essa força caracterizada no Livro III da obra é, então, uma força relativa. A fraqueza que a ela se opõe consiste, mais particularmente, no desequilíbrio entre força e desejo. Esse desequilíbrio se deve, por um lado, à extensão da imaginação para além da realidade e, por outro, às paixões, que fazem com que o sujeito almeje objetos inacessíveis e ilusórios do ponto de vista de sua condição: «São nossas paixões que nos tornam fracos, pois fora

$18 \mathrm{lbid}$., p. 305. 
preciso, para contentá-las, mais forças do que nos dá a natureza"19. Cabe notar que estamos aqui no plano da educação da natureza, seguindo o percurso natural do desenvolvimento das faculdades do espírito e dos órgãos corporais. É preciso relativizar essa força porque, essa fase da vida é caracterizada como um momento de fraqueza. Se, ainda assim, o jovem Emílio é considerado forte, é porque possui uma força maior do que a necessária para atender suas necessidades. Contudo, essa força é apenas relativa, pois ele ainda não conhece aquela necessidade que Rousseau observa ser «a mais violenta», «a mais terrível» ${ }^{20}$. Ora, o que seria essa necessidade, ao mesmo tempo tão violenta e tão terrível, somente a partir da qual se pode falar em força absoluta?

No momento em que descobre a sexualidade, Emílio encontra-se numa fase em que as faculdades do espírito existem apenas virtualmente, e onde não há propriamente um vínculo afetivo, moral e social. $\mathrm{O}$ método negativo propõe acompanhá-lo nesse ritmo natural, distanciando-o dos preconceitos, dos vícios, das paixões, enfim, de todos os males da sociedade. Nesse sentido, ele é educado para ser independente, para bastar-se a si mesmo. Rousseau é claro sobre a condição da criança nesse período: "Não somente ela pode bastar-se a si mesmo, como tem ainda mais força de que precisa; é o único momento de sua vida em que isso aconteces ${ }^{21}$.

Não há muitas passagens em que Rousseau trata desse tema no Emílio. Costuma-se chamar atenção para o materialismo do sábio ${ }^{22}$, uma espécie de moral sensitiva, baseada em princípios de cunho empirista segundo os quais não há idéias a priori acerca dos objetos morais. Toda a moralidade pareceria, nesse sentido, carecer de fundamentação. Mas não é isso que ocorre. Para nosso autor, os princípios morais não são da ordem da razão, mas pertencem ao âmbito da consciência moral, e esta se forma a partir daqueles princípios anteriores ao desenvolvimento da razão, o amor de si e a piedade natural.

\footnotetext{
19 Ibid., Livro III, p. 426.

$20 \mathrm{Ibid}$., Livro III, p. 426: "Aos doze ou treze anos as forças da criança desenvolvem-se muito mais rapidamente que suas necessidades. A mais violenta, a mais terrível não se faz ainda sentir; o próprio órgão permanece imperfeito e parece, para sair da imperfeição, esperar que sua vontade o leve a isso". ${ }^{21}$ Ibid., Livro III, p. 426.

${ }^{22}$ Em nota 4 ao Emílio, P. Burgelin supõe o materialismo do sábio quando chama atenção para a tarefa do governante, que seria a de impedir a anarquia da força ou da razão. Cf. Oeuvres complètes de J.-J. Rousseau, op. cit., v. 4, p. 1381-1382. Ver também sua obra La Philosophie de l'existence de J.J.Rousseau (Paris: PUF, 1952) em que comenta essa questão tendo como ponto de referência a descoberta de E. Gilson de uma obra não publicada de Rousseau intitulada "A Moral do Sentimento ou o Materialismo do Sábio".
} 
Lembremos que não há nenhum traço da consciência moral no homem que vive no puro estado de natureza, tal como é descrito no Discurso sobre a desigualdade. É preciso supor, pois, um longo percurso na história da humanidade para que nasçam os sentimentos e as afeições morais.

Nessa perspectiva, não há porque supormos um amor moral originário. As relações afetivas entre os seres da natureza e os sentimentos que as acompanham se desenvolvem depois, são posteriores aos princípios biológicos da procriação que permitem a continuidade da espécie. Não há, portanto, na natureza, uma comunidade unida por afeições recíprocas. As mães e seus filhotes permanecem unidos apenas enquanto fala a necessidade; assim que as crianças podem alimentar-se sozinhas, mães e filhos se separam. Entre os casais ocorre de modo similar: união entre os sexos para o acasalamento, sem nenhuma afeição moral. É preciso, pois, distinguir amor físico e amor moral. Segundo Rousseau, o amor do ponto de vista físico é um desejo geral que leva um sexo a se unir ao outro, do ponto de vista moral é escolha do parceiro, determinação e fixação do desejo. " $E$ fácil ver que o moral no amor é um sentimento factício; nascido do uso da sociedade ${ }^{223}$. Não há qualquer sentimento moral, mas apenas desejos ligados à natureza física e biológica. A construção do objeto dos desejos é, já, para nosso autor, elaboração, mais ou menos sofisticada, da razão.

Entre as paixões e os desejos, alguns supõem o desenvolvimento das faculdades mentais. De qualquer modo, para Rousseau, grande parte de nossas paixões são factícias, artificiais, cuja aparição é propiciada pelas condições de vida em sociedade, pelos costumes adquiridos. Aqui incluímos também a inveja, a vingança, o ciúme, assim como o amor próprio, a vaidade e o orgulho. Toda a infância de Emílio, até os doze anos, era orientada pela educação negativa, pela qual se tratava de preservá-lo do erro, das injustiças e dos vícios ${ }^{24}$. O período em que nascem as paixões mais fortes e violentas, caracterizado no Livro III do Emílio, aponta para a urgência de introduzi-lo nas primeiras lições sobre as relações sociais; Assim, seu tutor o faz ler Robinson Crusoé, ensina-lhe a ter uma noção da propriedade privada, introduz o princípio da utilidade em seu discurso e mostra-lhe como a sociedade é organizada pela divisão do trabalho. Não se trata ainda de chamar atenção às leis e à comunidade política - que só ocorrerá no Livro V

${ }^{23}$ Discurso sobre a desigualdade, op. cit., p. 157-158.

${ }^{24}$ Cf. Emílio, Livro II, op. cit., p. 323. 
da obra e que pressupõe os ensinamentos morais e religiosos, introduzidos no Livro IV - mas é preciso mostrar-lhe que não vive só e isolado.

É como se ensinar-lhe as primeiras noções de dever e de bom convívio fosse uma alternativa para equilibrar a violência das paixões. Se as paixões humanas não fossem violentas não precisaríamos de leis e normas de conduta. À revelia de suas aspirações mais nobres, atreladas aos sentimentos morais, à percepção da ordem, do bem, da justiça e da beleza do universo, a humanidade perece e se degrada continuamente. Quanto mais medita, mais se deprava. As perversões implicadas nas paixões humanas merecem aqui destaque, pois somente seu exame na obra de Rousseau nos permite concluir o estudo sobre o tema da morte moral. A morte moral anuncia, pela negativa, os artifos de fé apresentados no discurso do vigário saboiano. Estamos no Livro IV do Emílio. Vale a passagem pela leitura de algumas passagens de sua outra obra, o romance epistolar Júlia ou Nova Heloísa.

Protagonista do romance, Júlia provará ser uma mulher virtuosa: ela sacrifica suas paixões pelos deveres do bom convívio familiar e nisto encontra sua felicidade. Apaixonada por Saint-Preux, casa-se com o barão de Wolmar. A carta que nos interessa é de juventude, antes do casamento, carta na qual ela marca um encontro com seu amado em um chalé no campo, cujos telhados podem cobrir (ou ocultar) o amor e o prazer. Esses dois sentimentos, amor e prazer, aparecem aqui ligados à simplicidade rústica. $\mathrm{O}$ chalé se situa nos arredores da casa de sua prima, no campo, onde ficará hospedada enquanto seus pais precisam viajar para Berne. O tom empregado por Júlia é condenado por alguns leitores críticos, que não o consideram compatível com seu caráter. Não nos cabe aqui tomar partido quanto à retidão moral de nossa heroína nesse momento de sua trajetória rumo à virtude. Fala-se em libertinagem, o que não é de todo espantoso, já que Rousseau trata dos vários aspectos do sentimento amoroso, do qual seguramente o aspecto físico não é excluído.

Todavia, para o nosso autor, junto ao amor físico existe um amor de ordem superior, inteiramente compatível com os deveres da humanidade! O convite apaixonado que Júlia endereça a Saint-Preux não é isento de ambigüidades: ao mesmo tempo em que propõe prazer e paixão, sem o sacrifício à honestidade, refere-se também aos limites invioláveis e às leis que o dever impõe. A resposta de Saint-Preux, também apaixonada, está mais distante da razão e mais próxima do delírio: 
"Parece-me que o campo sorri, as plantas estão mais vivas, o ar mais puro e o céu mais sereno; o canto dos pássaros parece mais terno e mais voluptuoso [...] um charme secreto embeleza todos os objetos ou fascina meus sentidos; eu diria que a terra se prepara para formar a seu feliz amante uma cama nupcial digna da beleza que ele adora e do fogo que o consome [...] levemos o sentimento do prazer aos lugares que só oferecem sua vaga imagem; vamos animar toda a natureza, ela é morta sem o fogo do amor 25 ."

Essas passagens da obra Júlia ou Nova Heloísa confirmam a preocupação do autor com a caracterização de planos distintos da moralidade. No Discurso sobre a desigualdade notávamos haver a afirmação dos princípios anteriores à razão - amor de si e piedade natural - que, embora pré-morais, acabam se desdobrando e dando origem aos sentimentos morais, tema do Emílio. A diferença entre esses princípios e os sentimentos morais permanece, ainda assim, já que, para o autor, tais princípios são indeteminações do ponto de vista da moralidade. No romance epistolar Júlia, assistimos também a essa divisão entre dois aspectos do sentimento amoroso, e sai vitorioso o amor virtuoso, sentimento superior, aquele que leva Júlia a dedicar-se até à morte à virtude e ao sacrifício de suas paixões. A ênfase, porém, não reside simplesmente na anulação das aspirações individuais, dos desejos e paixões humanas, mas no vínculo inquebrantável entre os sentimentos morais - para Rousseau, de origem espiritual - e uma ordem transcendente, divina, fonte da perfeição, do bem, da justiça e da beleza, elementos que caracterizam para o autor a verdadeira felicidade.

A crítica política que empreende Rousseau em sua obra completa-se em suas considerações acerca dos sentimentos morais. Essa crítica orienta o tratamento do tema da alienação da liberdade na sociedade civil, como aparece no Discurso sobre a desigualdade, e acaba levando-o à explicitação das condições da participação política com a proposta de uma nova versão para a teoria contratual. O presente estudo nos mostra que essa crítica não se dirige apenas aos princípios abstratos do direito político. Além dos aspectos jurídicos que encontramos em sua obra Contrato social, há que se ressaltar a importância do projeto pedagógico apresentado no Emílio, sobretudo, o

${ }^{25}$ Cf. Júlia ou a Nova Heloísa, Parte I, Carta 38. In: Oeuvres complètes de Jean-Jacques Rousseau, op. cit., v. 2, p. 115-116. 
percurso de suas concepções antropológicas. É para a economia dos desejos que essa obra nos aponta quando se volta à análise das paixões, às concepções de liberdade, força e virtude e à fundamentação dos sentimentos morais.

Chamávamos frequentemente atenção para o diagnóstico de Rousseau aos males de seu tempo, sua crítica à razão moderna e ao projeto dos philosophes, sua crítica ao desenvolvimento cego das artes e das ciências. Para ele, a crença cega no progresso apresenta como contrapartida a perversão, resultado da reprodução irrefreada de nossos desejos e necessidades, extensão extremada do plano volitivo, cujo resultado é o entorpecimento da alma, incredulidade libertina, manifestação negativa da fraqueza humana. Retarnos-á mostrar como todos esses aspectos da natureza humana, atrelados ao seu diagnóstico acerca dos males da civilização, estão intimamente ligados às discussões sobre os abusos do poder. Poder, aqui, tomado não apenas no sentido jurídico, como atribuição contratual implicada nas relações entre governantes e governados, mas, sobretudo, como elemento interno, estrutural e constitutivo da rede de relações construída na esfera econômica e social. Depois de tanta ênfase nas interpretações idealistas da obra de Rousseau, é essa materialidade, presente fortemente nos textos do XVIII francês, que nos cabe ressaltar. Vontade na obra de nosso filósofo se lê de dois modos, no sentido propriamente moral, que é o da vontade autodeterminada, aquela que leva ao pacto político, mas também no sentido material, vontade que perece diante das mazelas de uma sociedade corrompida e injusta. Entre esses dois sentidos, transitamos também entre a idéia da morte moral - que se manifesta literariamente na figura do interlocutor do vigário saboiano - e a possibilidade de uma restauração moral que passa pela política da vontade geral e, do ponto de vista antropológico, pela economia das forças, das paixões e dos desejos. 


\section{Referências bibliográficas}

BUFFIER, C. Traité de la Société Civile et du Moyen de se Rendre Heureux, en contribuant au Bonheur des Personnes avec qui l'on vit. Avec d'Observations sur divers Ouvrages Renomez de Morale. Paris: Pierre-François Giffart, 1726.

BURGELIN, P. La Philosophie de l'existence de J.-J. Rousseau. Paris: PUF, 1952.

CONDILLAC, E. Le Commerce et le Gouvernement. Genebra: Slatkine, 1980.

ENCICLOPÉDIA ou Dicionário Raciocinado das Ciências, das Artes e dos Ofícios. Discurso Preliminar e outros textos, ed. bilíngüe, trad. F. M. L. Moretto. Marília: Unesp, 1989.

ENCYCLOPÉDIE ou Dictionnaire Raisonné des Sciences des Arts et des Métiers, de Diderot e d'Alembert, nova impressão em fac-símile da primeira edição (1751-1780). Stuttgart: Bad Cannstatt, 1988.

HELVÉTIUS, C. De l'Esprit, segundo a ed. de 1758, texto revisado por J. Moutaux. Paris: Fayard, 1988 (Coleção Corpus des Oeuvres de Philosophie en Langue Française).

LOUGH, J. The Encyclopédie. Genebra: Slaktine, 1989.

MARUYAMA, N. A Moral e a filosofia política de Helvétius: uma discussão com J.J. Rousseau. São Paulo: Humanitas/Fapesp, 2005, 643 p.

RANG, M. Le dualisme anthropologique dans l'Émile. In: Jean-Jacques Rousseau et son Oeuvre. Problèmes et Recherches. Colloque de Paris, out. 1962, Comité National pour la Commémoration de J.J. Rousseau. Paris: Klincksieck, 1964, pp. 195-203.

ROUSSEAU, J. Oeuvres complètes de Jean-Jacques Rousseau. Paris: Gallimard, 19641995. 5 v. (Bibliothèque de la Pléiade)

VERBETES políticos da Enciclopédia de Direrot e d'Alembert. São Paulo; Marília: Discurso; Unesp, 2006. 